\title{
Influence of Modified Atmosphere Packaging on Postharvest Quality of Baby Spinach (Spinacia oleracea L.) Leaves
}

\author{
Ambani R. Mudau \\ Department of Life and Consumer Sciences, University of South Africa, \\ Private Bag X6, Florida 1710, South Africa
}

Puffy Soundy

Department of Crop Sciences, Tshwane University of Technology, Private Bag X680, Pretoria 0001, South Africa

\author{
Hintsa T. Araya \\ ARC-Roodeplaat Vegetable and Ornamental Plant Institute, Private Bag \\ X293, Pretoria 0001, South Africa
}

Fhatuwani N. Mudau'

Department of Agriculture and Animal Health, University of South Africa, Private Bag X6, Florida 1710, South Africa

Additional index words. leaf vegetable, storage temperature, sensory quality, gas composition, off odor

\begin{abstract}
The aim of the current study was to determine the influence of modified atmospheric pressure on the quality of baby spinach during storage. Treatments consisted of control [(normal air) $\left.\left(78 \% \mathrm{~N}_{2} ; 21 \% \mathrm{O}_{2}\right)\right]$, modified atmosphere (MA) $(5 \%$ $\mathrm{O}_{2} ; 15 \% \mathrm{CO}_{2} ;$ balance $\left.\mathrm{N}_{2}\right)$, storage temperature $\left(4,10\right.$, and $\left.20{ }^{\circ} \mathrm{C}\right)$, and number of days after storage $(0,3,6,9$, and 12). Parameters recorded are gas composition, weight loss, sensory quality, minerals and trace elements (Mg, Fe, and $\mathrm{Zn}$ ), flavonoids, and antioxidant activity. The results of this study demonstrated that in the headspace gas there was overall reduction in $\mathrm{O}_{2}$ and increase in $\mathrm{CO}_{2}$ levels over the storage period. After 6 days of storage, all samples in normal air irrespective of the storage temperature were found to fall short of acceptable marketability with regard to visual appearance. The total antioxidant activity and flavonoids were well maintained under controlled atmosphere (CA) at $4{ }^{\circ} \mathrm{C}$ when stored for 9 days.
\end{abstract}

The biggest problem faced by the food industry in South Africa is the maintenance of quality of fresh produce during postharvest storage (Munhuweyi et al., 2016). Attempts to reduce losses and maintain quality of fresh food, primarily fruits and vegetables, during postharvest storage has been a challenge and priority for the food industry (Velickova et al., 2013). Strategies to prolong the shelf life of fresh-cut vegetables during storage are necessary to preserve their nutritional value and to assure food safety (Conte et al., 2008; Ninfali and Bacchiocca, 2004).

Modified atmosphere packaging (MAP) is the technique of sealing actively respiring produce, fresh fruit and vegetables, in polymeric

\footnotetext{
Received for publication 10 Oct. 2017. Accepted for publication 6 Dec. 2017.

This work was financially supported by the Gauteng Department of Agriculture and Rural Development (GDARD; GUN number 359000).

${ }^{1}$ Corresponding author. E-mail: mudaufn@unisa. ac.za.
}

film packages to achieve the modification of the $\mathrm{O}_{2}$ and $\mathrm{CO}_{2}$ levels within the package atmosphere (Mir and Beaudry, 2004). The MA packaging technology is said to be efficient in maintaining shelf life of fresh produce during storage (Sandhya, 2010). Church and Parsons (1995) reported that the combination of oxygen $\left(\mathrm{O}_{2}\right)$, nitrogen $\left(\mathrm{N}_{2}\right)$, and carbon dioxide $\left(\mathrm{CO}_{2}\right)$ is frequently used when operating the MAP during storage, based on its efficiency and specific effect it has in slowing down the metabolism process of the produce. The high $\mathrm{CO}_{2}$ or low $\mathrm{O}_{2}$ concentrations diminish respiration rate, thus, reduces the occurrence of aerobic bacteria and deterioration rate of the stored product (Babic and Watada, 1996).

The concentrations of $\mathrm{O}_{2}$ in MAP during storage of fresh-cut fruits and vegetables for both quality and safety should range between $1 \%$ and $5 \%$ (Sandhya, 2010), whereas $\mathrm{CO}_{2}$ concentrations should be above $10 \%$ (Zagory and Kader, 1988). Izumi et al. (1997) demonstrated the benefits of low $\mathrm{O}_{2}$ atmospheres on spinach during storage. In addition, Gil et al. (1999) and Ko et al. (1996) reported reduced respiration rate, weight loss, and antioxidant loss on spinach stored in low $\mathrm{O}_{2}$ concentrations. There is limited data available describing storage requirement of baby spinach using MAP. Thus, the objective of this study was to determine the effect of CA on postharvest quality and shelf life of baby spinach (Spinacia oleracea L.).

\section{Materials and Methods}

Experimental site. The trial was carried out at the Agricultural Research Council Vegetable and Ornamental Plant Institute situated $\approx 25 \mathrm{~km}$ north of Pretoria on the KwaMhlanga Road (R573), Gauteng Province, South Africa, at lat. $25^{\circ} 59^{\prime} \mathrm{S}$; long. $28^{\circ} 35^{\prime} \mathrm{E}$. The study was initiated during mid-May to early July 2014 and repeated in June to late Aug. 2015, which was suitable for baby spinach production in South Africa.

Plant materials. Ohio, a baby spinach cultivar (Hygrotech, Pretoria, South Africa) was used for the study. Seedlings of baby spinach $(S$. oleracea $\mathrm{L}$.) were thinned after $10 \mathrm{~d}$ of days after planting (DAP). Plants were fertilized with a balanced nutrient solution that contained all nutrients as described by Nemadodzi et al. (2017) and Zikalala et al. (2016). The initial soil chemical analyses were determined using a procedure described by Hanlon et al. (1994). The field soil conditions were light sandy clay soils, with a $\mathrm{pH}$ ranging from 7.3 to 7.7. All plants were irrigated by using drip irrigation system. The trial was ended 37 DAP.

Treatment and experimental design. Treatments consisted of control $\left(78 \% \mathrm{~N}_{2}\right.$; $\left.21 \% \mathrm{O}_{2}\right)$, MA $\left(5 \% \mathrm{O}_{2} ; 15 \% \mathrm{CO}_{2} ;\right.$ balance $\mathrm{N}_{2}$ ), at temperatures $\left(4,10\right.$, and $\left.20{ }^{\circ} \mathrm{C}\right)$ and number of days $(0,3,6,9$ and 12$)$ arranged in a randomized block design with five replicates. Parameters recorded were gas composition, weight loss, sensory quality, minerals and trace elements ( $\mathrm{Mg}, \mathrm{Fe}$, and $\mathrm{Zn})$, flavonoids and antioxidant activity.

Weight loss. Baby spinach leaves were weighed using a digital electronic balance [Model MK-500C, DENVER instrument ( $\pm 0.001 \mathrm{~g})$; Sigma-Aldrich, St Louis, MO] at the beginning and end of each storage period expressed as percentage weight loss.

Gas composition. Headspace $\mathrm{O}_{2}$ and $\mathrm{CO}_{2}$ concentrations in packages of baby spinach were measured using a PBI Dansensor $\mathrm{CO}_{2} / \mathrm{O}_{2}$ gas analyzer (Checkmate 9000, Ringsted, Denmark) by inserting the needle of the measuring assembly through a septum adhered to the packaging container during every storage interval (Mampholo et al., 2013). At each sampling interval, five packages from atmosphere conditions were measured and thereafter, the mean value was determined.

Sensory analysis (visual appearance and off odor). Sensory attributes were scored based on the methods described by Medina et al. (2012) with slight modifications. Product quality was evaluated in fresh material and after 3, 6, 9, and $12 \mathrm{~d}$ of storage. Overall acceptance and odor evaluation was carried 
Table 1. Percentage cumulative weight loss of packaged baby spinach stored under modified atmosphere packaging $\left(5 \% \mathrm{O}_{2} ; 15 \% \mathrm{CO}_{2}\right.$; balance $\left.\mathrm{N}_{2}\right)$ and under untreated atmosphere $\left(78 \% \mathrm{~N}_{2} ; 21 \% \mathrm{O}_{2}\right)$ at 4,10 , and $20^{\circ} \mathrm{C}$ for $12 \mathrm{~d}$.

\begin{tabular}{|c|c|c|c|c|c|c|}
\hline \multirow[b]{3}{*}{ Storage duration (d) } & \multicolumn{6}{|c|}{ Wt loss $(\%)^{2}$} \\
\hline & \multicolumn{3}{|c|}{ Modified atmosphere packaging } & \multicolumn{3}{|c|}{ Untreated atmosphere } \\
\hline & $4{ }^{\circ} \mathrm{C}$ & $10^{\circ} \mathrm{C}$ & $20^{\circ} \mathrm{C}$ & $4{ }^{\circ} \mathrm{C}$ & $10^{\circ} \mathrm{C}$ & $20^{\circ} \mathrm{C}$ \\
\hline 0 & $0.00 \mathrm{~b}$ & $0.00 \mathrm{~d}$ & $0.00 \mathrm{c}$ & $0.00 \mathrm{bc}$ & $0.00 \mathrm{c}$ & $0.00 \mathrm{~d}$ \\
\hline 3 & $0.39 \mathrm{a}$ & $1.59 \mathrm{c}$ & $3.39 \mathrm{~b}$ & $0.06 \mathrm{c}$ & $3.14 \mathrm{~b}$ & $4.21 \mathrm{c}$ \\
\hline 6 & $0.55 \mathrm{a}$ & $2.93 \mathrm{~b}$ & $3.60 \mathrm{~b}$ & $0.61 \mathrm{~b}$ & $3.33 \mathrm{~b}$ & $6.23 \mathrm{~b}$ \\
\hline 9 & $0.89 \mathrm{a}$ & $3.08 \mathrm{~b}$ & $5.33 \mathrm{a}$ & $1.19 \mathrm{a}$ & $5.23 \mathrm{a}$ & $6.76 \mathrm{~b}$ \\
\hline 12 & $0.94 \mathrm{a}$ & $5.03 \mathrm{a}$ & $5.79 \mathrm{a}$ & $2.24 \mathrm{a}$ & $5.29 \mathrm{a}$ & $7.56 \mathrm{a}$ \\
\hline
\end{tabular}

${ }^{\mathrm{z}}$ Weight loss (\%) is presented as the mean of five replicates. Means in columns with different letters are significantly different $(P \leq 0.05)$ using Duncan's multiple range test.
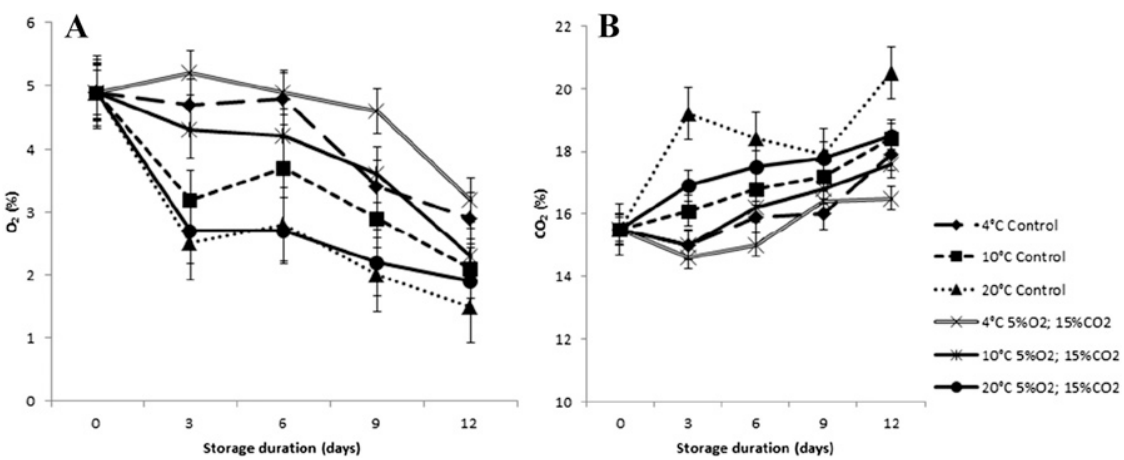

Fig. 1. Changes in headspace gas composition $\left[\% \mathrm{O}_{2}(\mathrm{~A})\right.$ and $\left.\% \mathrm{CO}_{2}(\mathrm{~B})\right]$ of baby spinach stored at 4,10 , and $20{ }^{\circ} \mathrm{C}$ for $12 \mathrm{~d}$ in modified atmosphere $\left(5 \% \mathrm{O}_{2} ; 15 \% \mathrm{CO}_{2}\right.$; balance $\left.\mathrm{N}_{2}\right)$ and untreated atmosphere $\left(78 \% \mathrm{~N}_{2} ; 21 \% \mathrm{O}_{2}\right)$. Each value represents the mean of five determinations at each temperature \pm SE. Data points indicate mean gas composition SE. out by 10 trained panelists between 23 and 45 years of age ( $70 \%$ females and $30 \%$ males). In an assessment of postharvest decay condition, the samples were individually scored in hedonic scale arranged as 1 to 9 [where $9=$ excellent, $7=$ good (some leaves slightly yellowed or decayed), 5 = fair (with acceptable marketability), 3 = poor (dominated by yellow or decayed leaves), $1=$ extremely poor (inedible)]. With regard to odor, a scale of 1 to 9 was applied: where $9=$ excellent, $7=$ slightly off-odor, 5 = moderate off-odor, 3 = strong off-odor, and 1 = intolerable off-odor.

Leaf color. Surface color of spinach leaves was objectively measured using a Minolta CR-400 chromameter (Minolta, Osaka, Japan), calibrated with a white tile. Five leaves per atmosphere condition were measured at $0,3,6,9$, and $12 \mathrm{~d}$ of storage. The change in total color that occurred during the storage $(\Delta E)$ was determined using the formula:

$$
\Delta E=\left[\left(\Delta L^{*}\right)^{2}+\left(\Delta a^{*}\right)^{2}+\left(\Delta b^{*}\right)^{2}\right]^{1 / 2}
$$

where $\Delta L^{*}, \Delta a^{*}$, and $\Delta b^{*}$ are differences in spinach color between day 0 and the sampling day (Pandrangi and LaBorde, 2004).

Mineral and trace elements. All mineral and trace elements were analyzed using a method described by van der Walt et al. (2009).

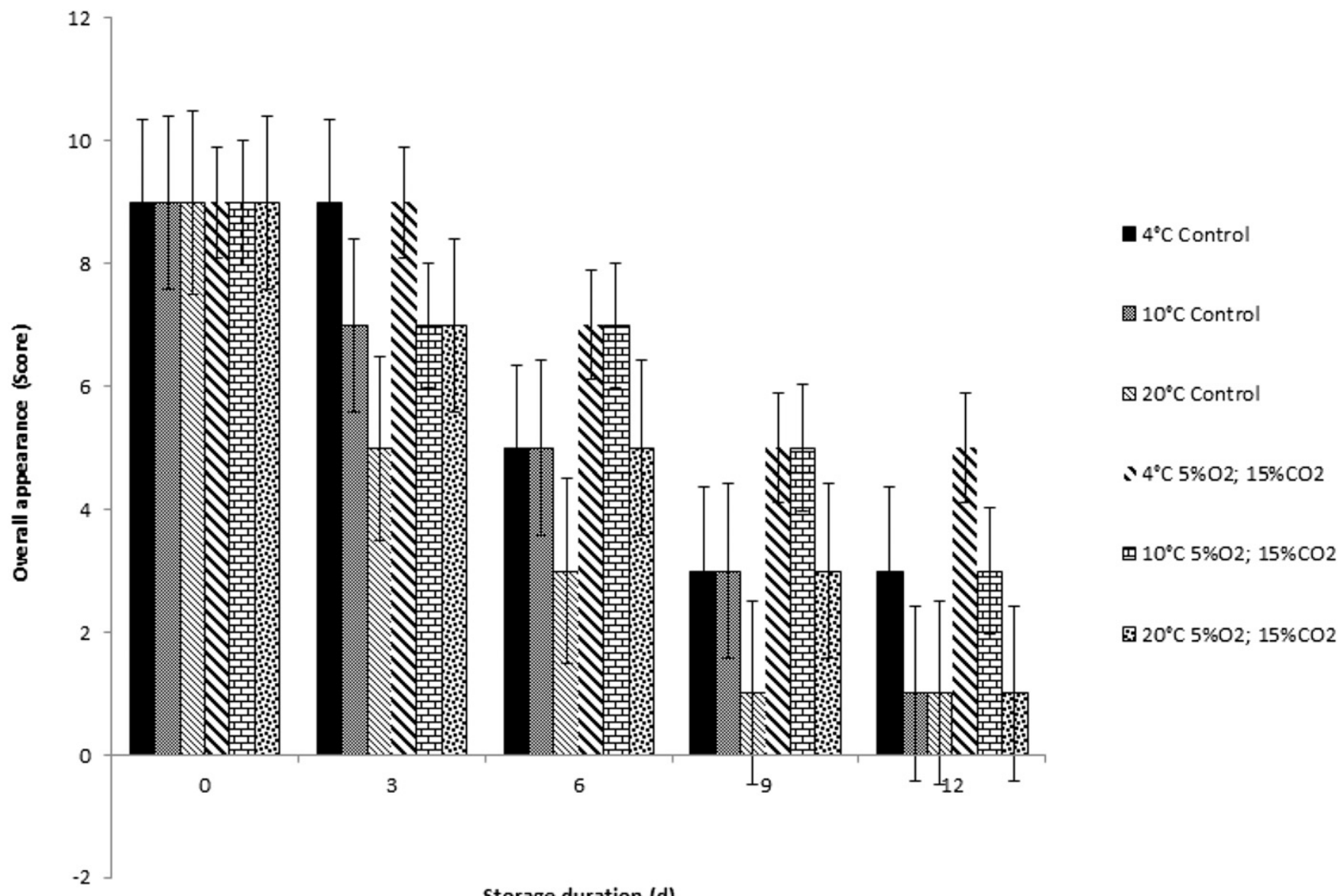

Fig. 2. Influence of modified atmosphere and normal air conditions on overall appearance in baby spinach leaves stored at 4,10 , and $20^{\circ} \mathrm{C}$ for $12 \mathrm{~d}$. Data points indicate mean score $\mathrm{SE}$. 
Determination of antioxidant activity. Antioxidant activity (by free radical scavenging) of the extracts was determined using Trolox equivalent antioxidant capacity assay as described by Awika and Rooney (2004).

Evaluation of total flavonoid content. The total flavonoids were measured using a modified calorimetric method described by Yoo et al. (2008) and slightly modified by Mudau et al. (2015).

Statistical analysis. Data were subjected to analysis of variance using IBM SPSS statistics version 23.0. Means were separated using Duncan's multiple range test. The Wilcoxon Mann-Whitney test was used for sensory analysis to compare treatments applied during postharvest. The significant differences were considered at $P<0.05$.

\section{Results}

Weight loss (MAP). Table 1 showed that baby spinach leaves stored under MA from 3 to $12 \mathrm{~d}$ significantly reduce $\%$ weight loss. The difference between the highest and lowest weight loss was $0.94 \%$ when stored at $4{ }^{\circ} \mathrm{C}$, whereas at 10 and $20^{\circ} \mathrm{C}$, the highest weight loss was $5.03 \%$ and $5.79 \%$. All treatments significantly maintained percentage weight loss with the highest achieved at $12 \mathrm{~d}$ of storage.

Untreated (normal) atmosphere. Percentage weight loss (\%) in spinach leaves stored under normal air showed demonstrated similar trends in all storage temperature for $12 \mathrm{~d}$ (Table 1). After $12 \mathrm{~d}$, the highest weight loss $(7.56 \%)$ was observed in samples stored at $20{ }^{\circ} \mathrm{C}$. The least weight loss $(2.24 \%)$ was observed in the samples stored at $4{ }^{\circ} \mathrm{C}$. This storage temperature showed great potential in maintaining weight than at 10 and $20{ }^{\circ} \mathrm{C}$. However, the CA samples maintained more weight greater than those that were exposed to untreated atmosphere.

Gas composition. Figure 1A and B demonstrated the changes in the headspace gas composition of baby spinach in MA and normal air conditions at different temperatures over the storage period. There was a rapid decrease of $\mathrm{O}_{2}$ ranging from $4.9 \%$ to $2.5 \%$ on the $3 \mathrm{~d}$ of storage at $20^{\circ} \mathrm{C}$. A faster $\mathrm{CO}_{2}$ production was observed at $20^{\circ} \mathrm{C}$ on the $3 \mathrm{~d}$ of storage under baby spinach leaves stored at normal air condition, ranging from $15.5 \%$ to $19.2 \%$. Irrespective of gas conditions, samples stored at $20^{\circ} \mathrm{C}$ had the lowest $\mathrm{O}_{2}$ and the highest $\mathrm{CO}_{2}$ followed by those stored at 10 and $4{ }^{\circ} \mathrm{C}$.

Sensory analysis. Significant differences $(P<0.05)$ in the overall visual appearance and off-odor were observed among baby spinach samples stored in MA and normal air condition at different temperatures over the storage duration (Figs. 2 and 3). Samples from all treatments scored high with similar values for day 0 and no significant difference was noted $(P>0.05)$, whereas on the day 3 , samples stored in normal air at $20^{\circ} \mathrm{C}$ showed signs of a faster deterioration in quality from all other treatments (Fig. 2). Samples in MA at $10{ }^{\circ} \mathrm{C}$ had better quality than those in normal air condition stored at $4{ }^{\circ} \mathrm{C}$ on the 6 and $9 \mathrm{~d}$ of storage. In comparison between samples in MA and normal air conditions, significantly faster quality deterioration was observed in samples exposed to normal air. This was evident in that after $6 \mathrm{~d}$ of storage; all samples in normal air irrespective of the storage temperature were found to fall short of acceptable marketability. On the $12 \mathrm{~d}$, samples in CA stored at $4{ }^{\circ} \mathrm{C}$ still had overall quality for acceptable marketability.

Moderate off-odor was observed after $12 \mathrm{~d}$ of storage in spinach samples under MA when stored at $4{ }^{\circ} \mathrm{C}$ (Fig. 3). However, samples exposed to normal air stored at similar temperature after $12 \mathrm{~d}$ had strong off-odor. Furthermore, no significant differences $(P>0.05)$ were observed among samples under MA and normal air at $4{ }^{\circ} \mathrm{C}$ during the entire storage period. Similar trend was observed in samples stored at the storage temperature of 10 and $20^{\circ} \mathrm{C}$ for modified and normal air conditions, respectively. Samples exposed to normal air at $20{ }^{\circ} \mathrm{C}$ revealed a defect which occurred rapidly because a strong off odor was evident on day 6 of storage.

Leaf color. Statistical analysis of color changes in spinach leaves during storage showed slight differences in MA at all three storage temperatures. In general, the nature of samples stored under normal air showed significantly lower $\mathrm{a}^{*}$, higher $\mathrm{b}^{*}$, and higher chroma than samples stored in MA. The color differences $(\Delta E)$ increased $(P<0.05)$ in both $\mathrm{MA}$ and normal air samples and most rapid changes were observed at $20{ }^{\circ} \mathrm{C}$ (Fig. 4). Whereas, samples stored at 4 and $10{ }^{\circ} \mathrm{C}$

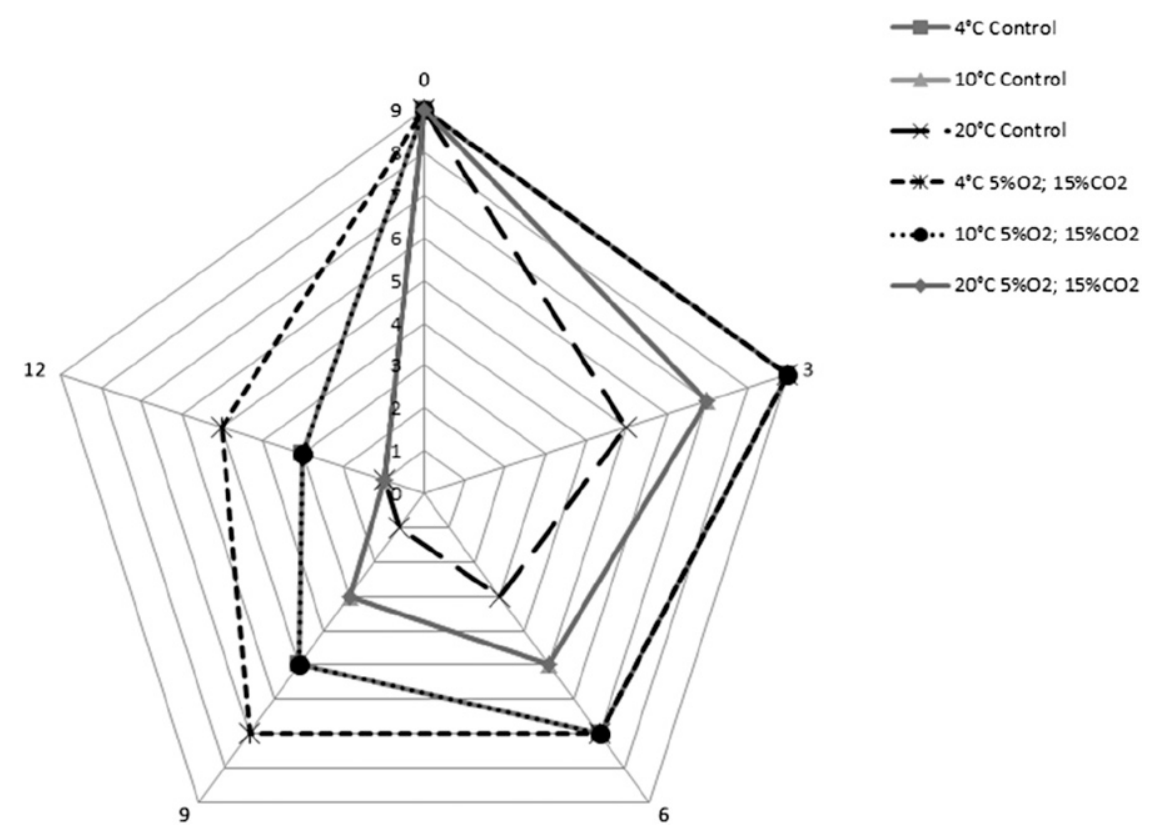

Fig. 3. Influence of modified atmosphere and normal air conditions on the off-odor in baby spinach leaves stored at 4,10 , and $20^{\circ} \mathrm{C}$ for $12 \mathrm{~d}$.

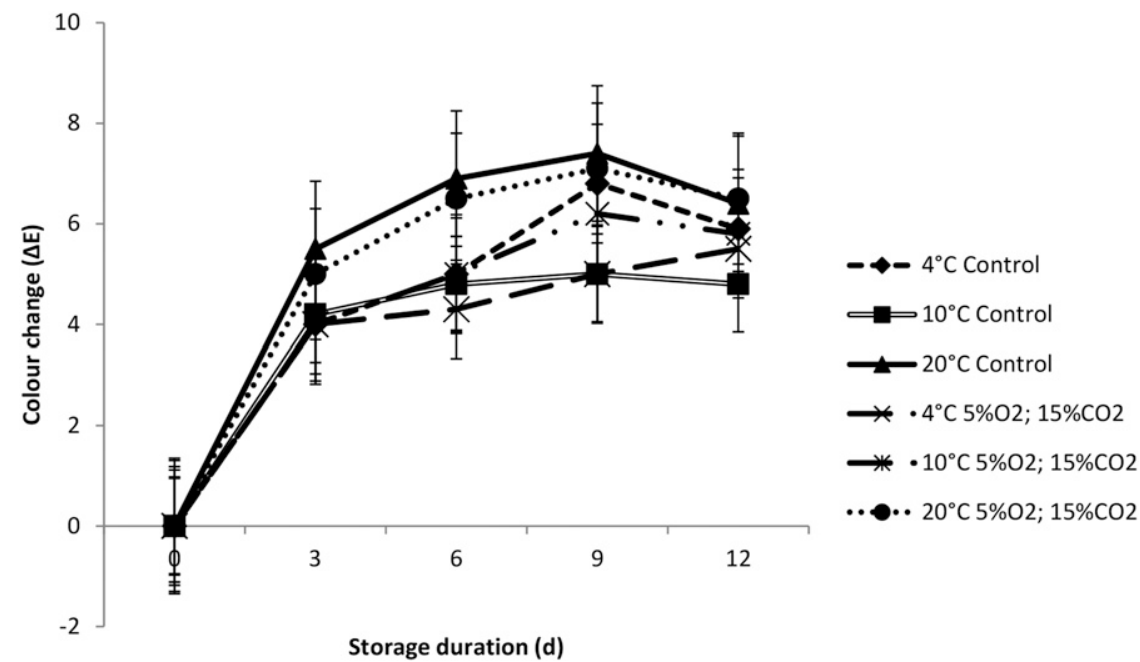

Fig. 4. Change in total color $(\Delta E)$ of spinach packaged with modified atmosphere $\left(5 \% \mathrm{O}_{2} ; 15 \% \mathrm{CO}_{2}\right.$; balance $\left.\mathrm{N}_{2}\right)$ and control $\left(78 \% \mathrm{~N}_{2} ; 21 \% \mathrm{O}_{2}\right)$ at 4,10 , and $20^{\circ} \mathrm{C}$ for $12 \mathrm{~d}$. Each value represents the mean of five determinations at each temperature \pm SE. Data points indicate color change SE. 

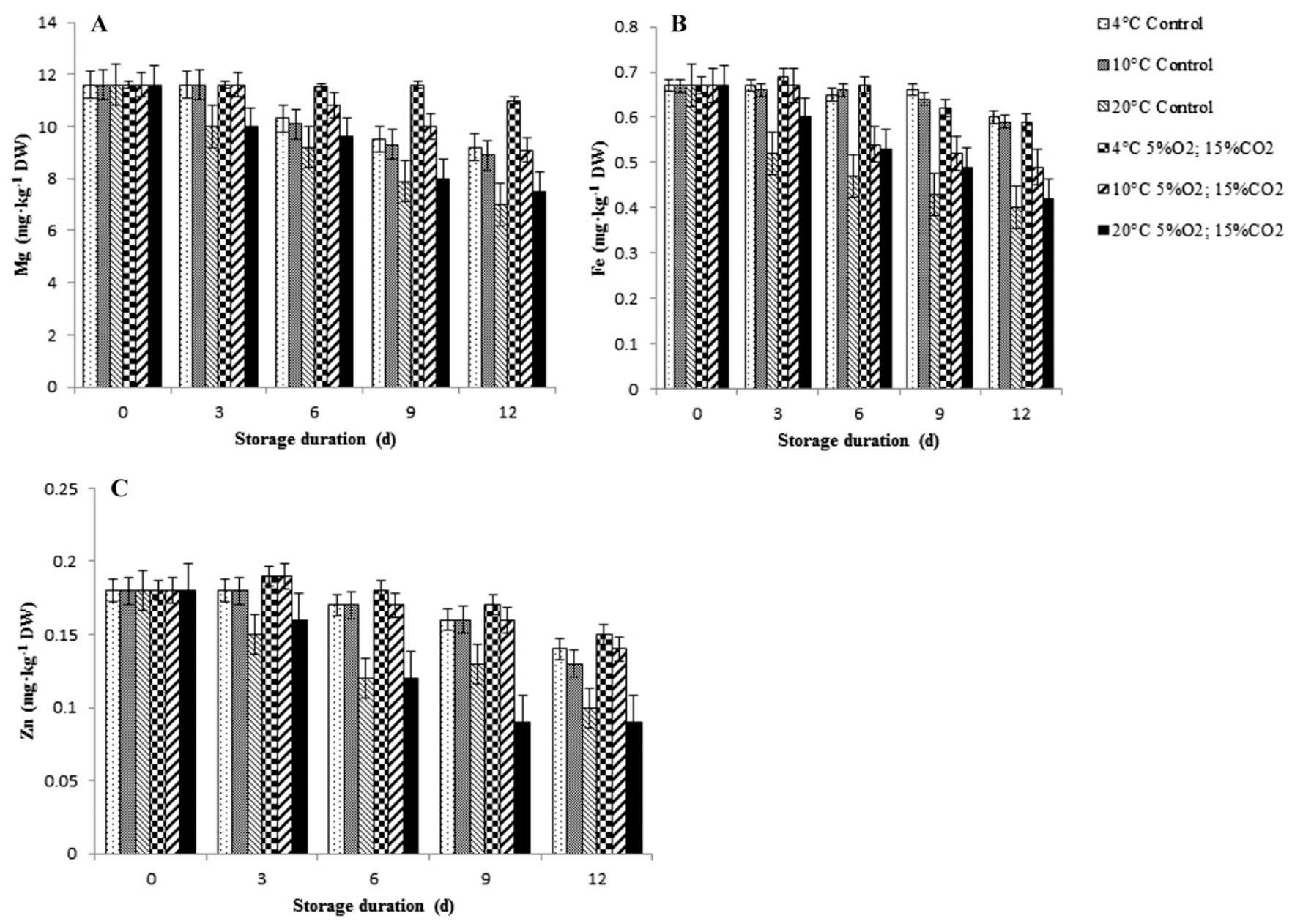

Fig. 5. Effect of modified atmosphere on the $\mathrm{Mg}(\mathrm{A}), \mathrm{Fe}(\mathrm{B})$, and $\mathrm{Zn}(\mathrm{C})$ in the spinach leaves stored at 4, 10, and $20^{\circ} \mathrm{C}$ for $12 \mathrm{~d}$. Data points indicate mean sE.

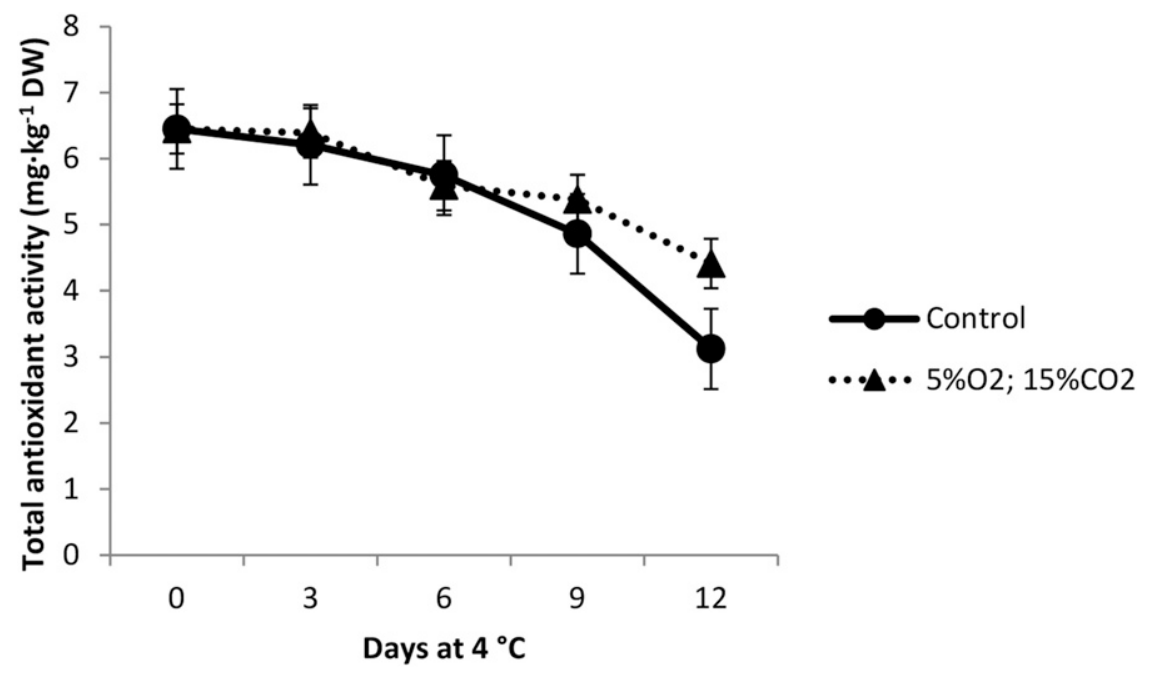

Fig. 6. Total antioxidant activity (mg.kg-1 DW) of baby spinach leaves stored under modified atmosphere $\left(5 \% \mathrm{O}_{2} ; 15 \% \mathrm{CO}_{2} ;\right.$ balance $\left.\mathrm{N}_{2}\right)$ and control $\left(78 \% \mathrm{~N}_{2} ; 21 \% \mathrm{O}_{2}\right)$, at $4{ }^{\circ} \mathrm{C}$ for $12 \mathrm{~d}$. Data points indicate mean total antioxidant activity SE.

remained constant during the entire storage duration.

Mineral and trace elements. Modified atmospheric pressure revealed a similar effect of normal air on $\mathrm{Mg}, \mathrm{Fe}$, and $\mathrm{Zn}$. Magnesium concentration was highly retained in the lowest storage temperature regardless of the surrounding gas composition on the spinach leaves (Fig. 5A). After $12 \mathrm{~d}$ of storage, spinach leaves stored at $4{ }^{\circ} \mathrm{C}$ under MA and normal air conditions had $\mathrm{Mg}$ concentration of 11 and $9.2 \mathrm{mg} \cdot \mathrm{kg}^{-1}$ dry weight (DW). The least concentration of $\mathrm{Mg}$ was pronounced in spinach leaves stored at $20{ }^{\circ} \mathrm{C}$ under MA $\left(7.5 \mathrm{mg} \cdot \mathrm{kg}^{-1} \mathrm{DW}\right)$ and normal air $\left(7 \mathrm{mg} \cdot \mathrm{kg}^{-1} \mathrm{DW}\right)$. The rate in which $\mathrm{Fe}$ was declining was very slow compared with $\mathrm{Mg}$ and $\mathrm{Zn}$ concentration. Iron concentration ranged between 0.4 and $0.67 \mathrm{mg} \cdot \mathrm{kg}^{-1}$ DW in both gas conditions (Fig. 5B). Iron concentration was not significantly different $(P>0.05)$ between MA and normal air conditions. From 3 to $9 \mathrm{~d}$ of storage, $\mathrm{Zn}$ concentrations were similar at 4 and $10{ }^{\circ} \mathrm{C}$ (Fig. 5C).

Total antioxidant activity. Total antioxidant activity decreased in all treatments; however, the baby spinach stored under MA showed better activity when compared with those stored in a normal air. During storage period at $4{ }^{\circ} \mathrm{C}$, total antioxidant activities were closer in both MA and normal air conditions. Nevertheless, at the end of the experiment baby spinach leaves stored under MA demonstrated a higher maintenance of total antioxidant activity when compared with those stored in the normal air environment (Fig. 6)

On the other hand, it was found that the total antioxidant activity in baby spinach leaves stored under normal atmosphere drastically decreased, after day 3 in particular, from 6.45 to $5.58 \mathrm{mg} \cdot \mathrm{kg}^{-1} \mathrm{DW}$, whereas those stored under MA slightly decreased from 6.45 to $5.91 \mathrm{mg} \cdot \mathrm{kg}^{-1} \mathrm{DW}$ (Fig. 7). Thus, 
the total antioxidant activity was significantly affected as the difference was statistically significant. It can be concluded that the MA technique is ideal as it delays degradation of leaf pigment. Immediately, after day 3 of storage period, it was clear that the highest level of total antioxidant activity was observed in the baby spinach leaves stored at $4{ }^{\circ} \mathrm{C}$ under MA when compared with the other samples stored at 10 and $20^{\circ} \mathrm{C}$ under both MA and normal air atmosphere (Figs. 5-7).

In fact, the total antioxidant activity in the baby spinach leaves stored under MA at $4{ }^{\circ} \mathrm{C}$ after 3 and $12 \mathrm{~d}$ of storage period was 6.39 and $4.41 \mathrm{mg} \cdot \mathrm{kg}^{-1} \mathrm{DW}$, respectively, as shown in Fig. 8. Whereas, the lowest total antioxidant activity after $3 \mathrm{~d}\left(3.65 \mathrm{mg} \cdot \mathrm{kg}^{-1} \mathrm{DW}\right)$ and $12 \mathrm{~d}\left(2 \mathrm{mg} \cdot \mathrm{kg}^{-1} \mathrm{DW}\right)$ was observed at $20{ }^{\circ} \mathrm{C}$ in baby spinach leaves stored under untreated atmosphere. Although the baby spinach leaves stored under normal atmosphere had shown very poor total antioxidant sustainability, baby spinach leaves stored at $4{ }^{\circ} \mathrm{C}$ resembled the steadiest of total antioxidant over those stored at 10 and $20{ }^{\circ} \mathrm{C}$ under normal air.

Total flavonoid content. Total flavonoids in samples stored in MA ranged from 6.12 to $25.14 \mathrm{mg} \cdot \mathrm{kg}^{-1} \mathrm{DW}$, whereas total flavonoids of untreated (normal) samples ranged from 5 to $25.14 \mathrm{mg} \cdot \mathrm{kg}^{-1} \mathrm{DW}$ in all three different temperatures (Figs. 9-11). Total flavonoid contents decreased as the storage duration increased in all treatments. However, baby spinach samples under MA when stored at $4{ }^{\circ} \mathrm{C}$ showed higher capacity to retain the high levels of total flavonoids from the beginning of storage until day 12 (Fig. 9). There was a significant difference between modified samples stored at 4 and $20{ }^{\circ} \mathrm{C}$ after day 6 of storage.

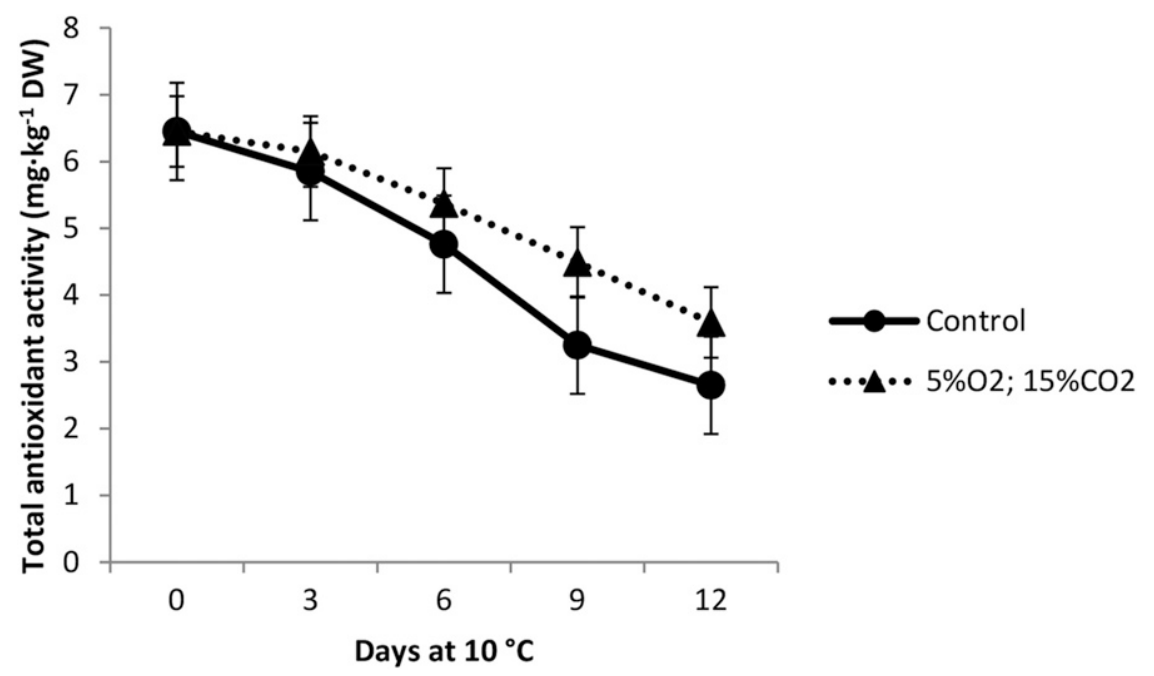

Fig. 7. Total antioxidant activity (mg. $\mathrm{kg}^{-1} \mathrm{DW}$ ) of baby spinach leaves stored under modified atmosphere $\left(5 \% \mathrm{O}_{2} ; 15 \% \mathrm{CO}_{2} ;\right.$ balance $\left.\mathrm{N}_{2}\right)$ and control $\left(78 \% \mathrm{~N}_{2} ; 21 \% \mathrm{O}_{2}\right)$, at $10{ }^{\circ} \mathrm{C}$ for $12 \mathrm{~d}$. Data points indicate mean total antioxidant activity SE.

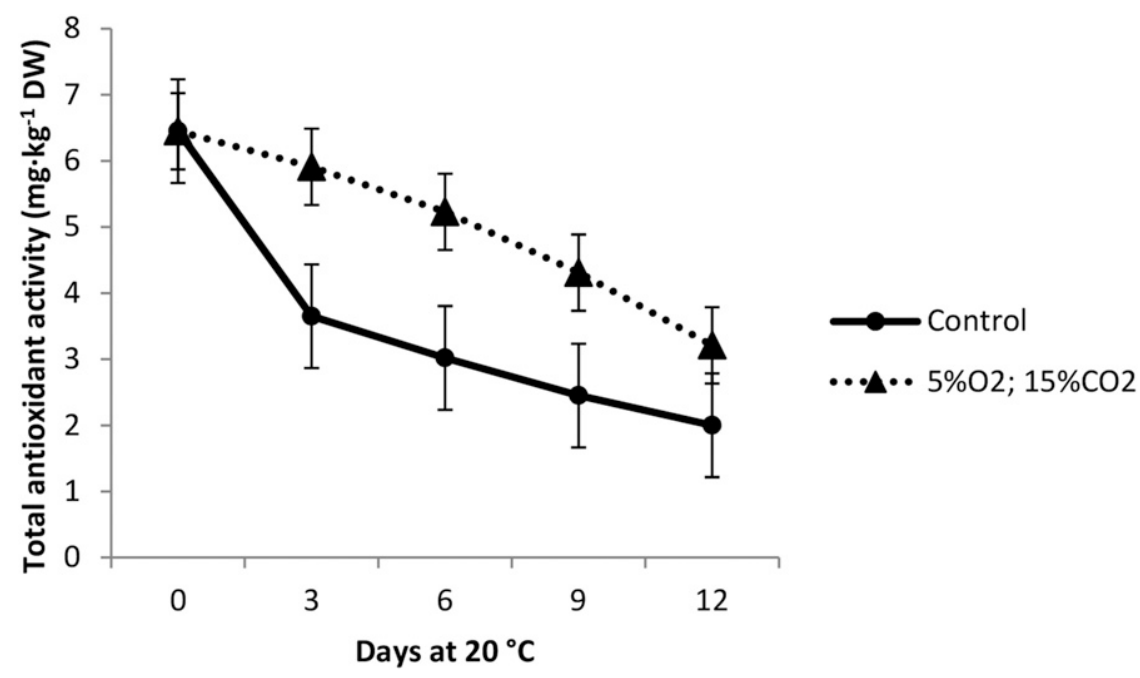

Fig. 8. Total antioxidant activity (mg.kg-1 DW) of baby spinach leaves stored under modified atmosphere $\left(5 \% \mathrm{O}_{2} ; 15 \% \mathrm{CO}_{2} ;\right.$ balance $\left.\mathrm{N}_{2}\right)$ and control $\left(78 \% \mathrm{~N}_{2} ; 21 \% \mathrm{O}_{2}\right)$, at $20{ }^{\circ} \mathrm{C}$ for $12 \mathrm{~d}$. Data points indicate mean total antioxidant activity SE.

\section{Discussion}

The headspace gas composition completely relies on the fresh produce $\mathrm{O}_{2}$ consumption and $\mathrm{CO}_{2}$ production rate when packaged and stored (Mastromatteo et al., 2012). The increase in $\mathrm{O}_{2}$ consumption and $\mathrm{CO}_{2}$ production with relative increase in temperature over storage time could be attributed to the respiration activity of baby spinach. Samples in CA had slow $\mathrm{O}_{2}$ consumption and $\mathrm{CO}_{2}$ production rate compared with those stored in normal air condition. Thus, the findings in this study suggest that CA coupled by low temperature over storage period could reduce respiration rate, which leads to extended shelf life of the fresh produce. Similar findings were obtained in previous studies for baby spinach (Kaur et al., 2011; Kou et al., 2014; Tudela et al., 2013). Furthermore, similar results were found by other authors for different vegetables (Leceta et al., 2015).

Weight loss during storage period varies depending on the vegetable, packaging conditions (include modified atmospheric pressure), and also, temperature levels. Modified atmosphere has proved to reduce weight loss compared with normal air. Similar findings were confirmed in the study conducted by Antmann et al. (2008), who observed a weight loss of $72 \%$ after $6 \mathrm{~d}$ of storage at $5{ }^{\circ} \mathrm{C}$ in unpackaged mushrooms, whereas mushroom in packaged conditions reduced weight loss. Reduced weight loss in plants stored under MA could be caused by the fact that the respiration rate is passive, and also carbohydrate resources were consumed slowly in the atmospheric condition. In this current study, weight loss increased with storage duration gradually. However, at higher temperature it has been observed that there is a rapid increase. This could be attributed to the fact that high temperature may increase the respiration rate which may result in dehydrated product. Mudau et al. (2015) and Watada et al. (1987) reported similar findings as greater loss of weight was observed in baby spinach samples stored at $20{ }^{\circ} \mathrm{C}$. Zenoozian (2011) reported the maximum weight loss of spinach during storage at 10 and $25^{\circ} \mathrm{C}$ when stored in normal air; however, active MA packaging had minimum loss of weight.

Spinach samples under MA were considered not acceptable for marketing after 9 and $12 \mathrm{~d}$ at 20 and $10{ }^{\circ} \mathrm{C}$, respectively. Similar findings were reported by Pandrangi and LaBorde (2004), who found that spinach under normal air stored at 4,10 , and $20{ }^{\circ} \mathrm{C}$ were commercially unacceptable after 8,6 , and $4 \mathrm{~d}$, respectively. Although less pronounced in their studies, we assume that the extended of commercial acceptability in our findings was effected by an introduction of modified atmospheric pressure.

The shelf life of the stored produce is pronounced to be influenced largely by sensory quality parameters, among others, odor, which may either invigorate or discourage consumers' consumption. Off-odor became notably more perceptible in spinach leaves 


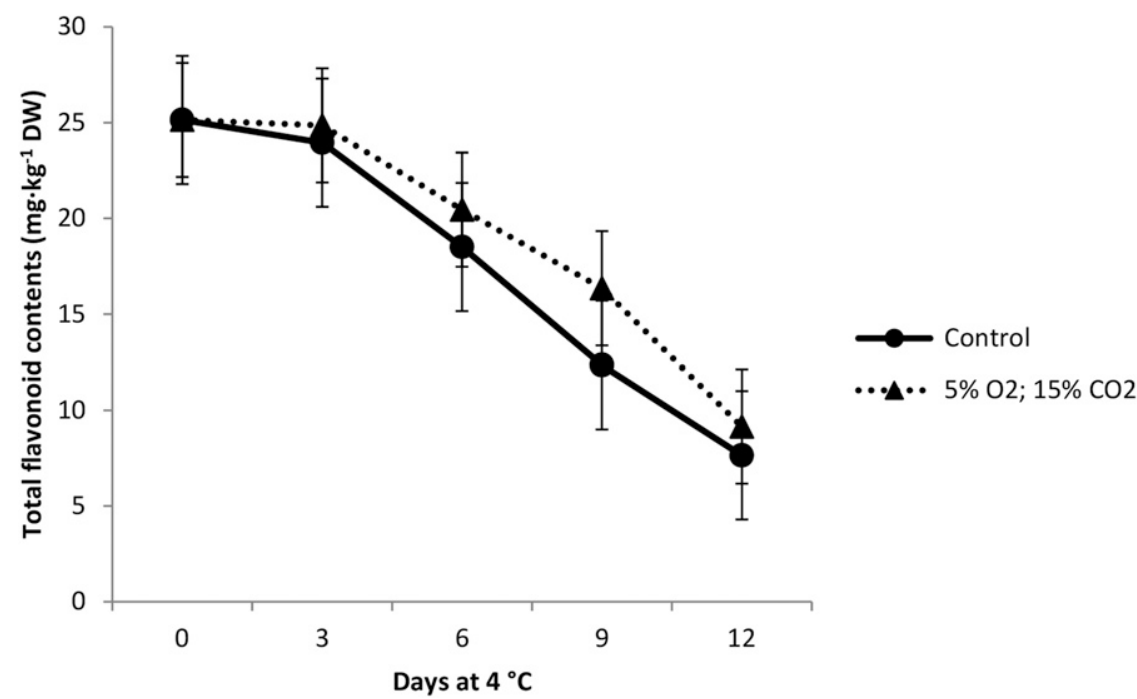

Fig. 9. Total flavonoid contents (mg. $\left.\mathrm{kg}^{-1} \mathrm{DW}\right)$ in baby spinach leaves stored under modified atmosphere $\left(5 \% \mathrm{O}_{2} ; 15 \% \mathrm{CO}_{2} ;\right.$ balance $\left.\mathrm{N}_{2}\right)$ and control atmosphere $\left(78 \% \mathrm{~N}_{2} ; 21 \% \mathrm{O}_{2}\right)$, stored at $4{ }^{\circ} \mathrm{C}$ for $12 \mathrm{~d}$. Data points indicate mean total antioxidant activity SE.

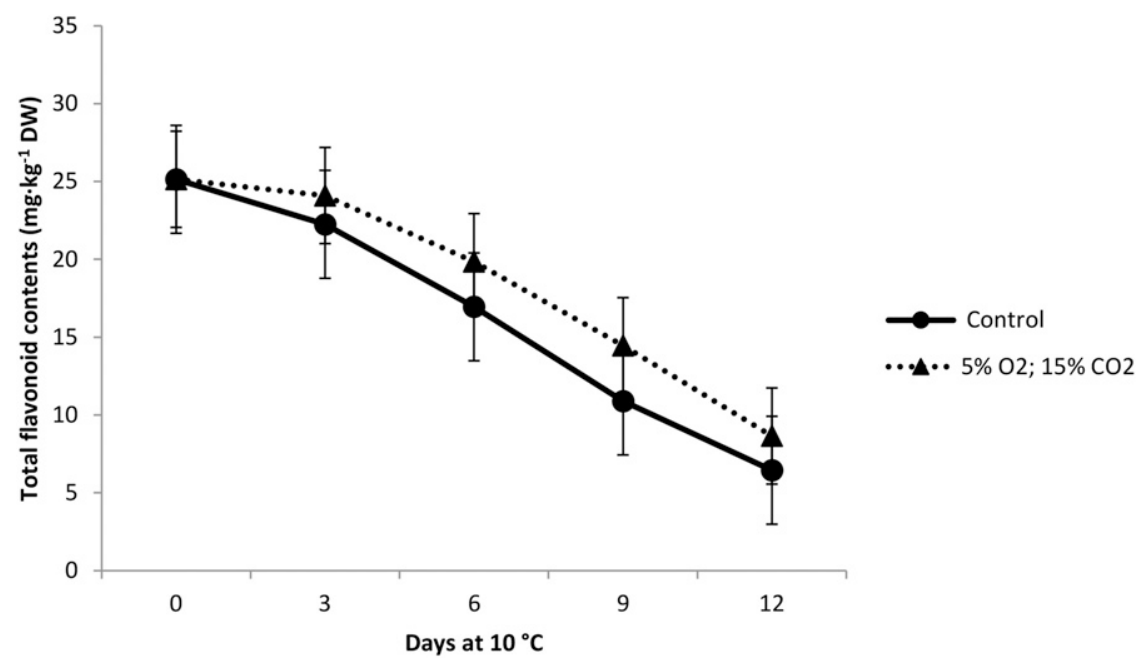

Fig. 10. Total flavonoid contents $\left(\mathrm{mg} \cdot \mathrm{kg}^{-1} \mathrm{DW}\right)$ in spinach leaves stored under modified atmosphere $(5 \%$ $\mathrm{O}_{2} ; 15 \% \mathrm{CO}_{2} ;$ balance $\left.\mathrm{N}_{2}\right)$ and control atmosphere $\left(78 \% \mathrm{~N}_{2} ; 21 \% \mathrm{O}_{2}\right)$, stored at $10{ }^{\circ} \mathrm{C}$ for $12 \mathrm{~d}$. Data points indicate mean total flavonoids SE.

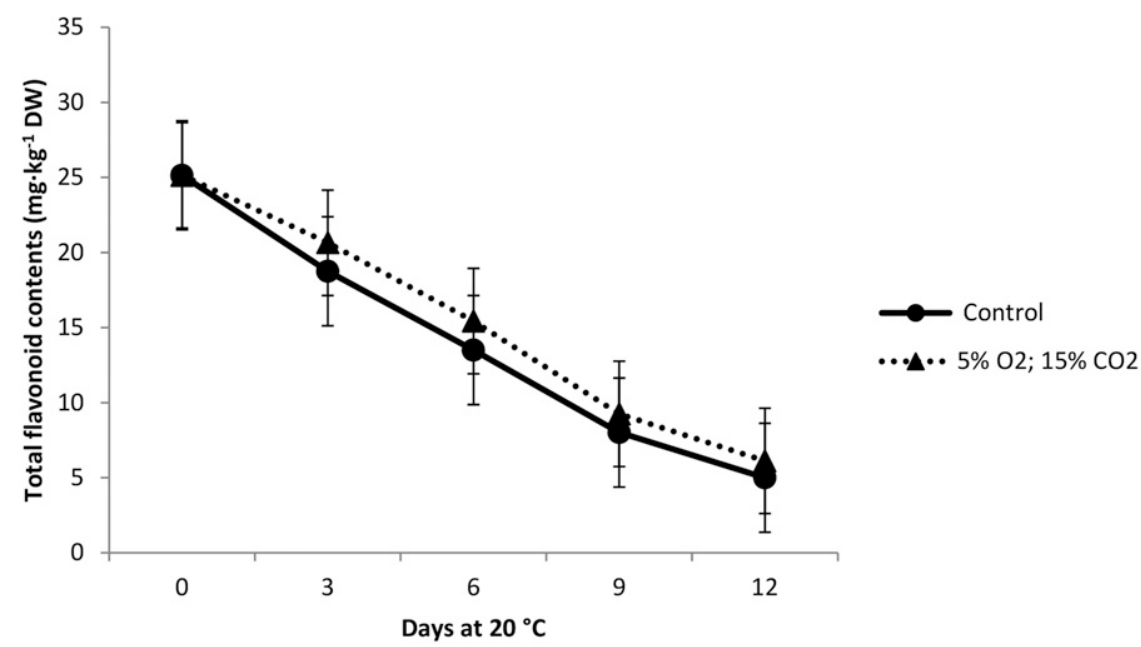

Fig. 11. Total flavonoid contents $\left(\mathrm{mg} \cdot \mathrm{kg}^{-1} \mathrm{DW}\right)$ in spinach leaves stored under modified atmosphere $(5 \%$ $\mathrm{O}_{2} ; 15 \% \mathrm{CO}_{2}$; balance $\left.\mathrm{N}_{2}\right)$ and control atmosphere $\left(78 \% \mathrm{~N}_{2} ; 21 \% \mathrm{O}_{2}\right)$, stored at $20{ }^{\circ} \mathrm{C}$ for $12 \mathrm{~d}$. Data points indicate mean total flavonoids SE. exposed to normal air stored at 10 and $20^{\circ} \mathrm{C}$ as the storage duration increased. When considering $\mathrm{O}_{2}$ evolution, oxygen uptake will rise with an increase in storage temperature Most importantly, low $\mathrm{O}_{2}$ and high $\mathrm{CO}_{2}$ concentrations retarded the respiration rate. Off-odor was less pronounced in MA samples stored at 4 and $10{ }^{\circ} \mathrm{C}$, whereas similar trend was observed with those samples exposed to normal air at $4{ }^{\circ} \mathrm{C}$. It was only MA samples stored at $4{ }^{\circ} \mathrm{C}$ which were found to be commercially acceptable after $12 \mathrm{~d}$ of storage. These findings were in agreement with results found by Tudela et al. (2013), who reported that baby spinach exposed to low $\mathrm{O}_{2}$ with $\mathrm{CO}_{2}$ was rejected after $10 \mathrm{~d}$ at $7{ }^{\circ} \mathrm{C}$.

According to Rizzo and Muratore (2009), color remains to be the core parameter that customers apply when judging the quality of vegetables. Our findings were similar to those reported by Pandrangi and LaBorde (2004). In their study, they found that there was no significant difference after 8,6 , and $4 \mathrm{~d}$ at 4 , 10 , and $20{ }^{\circ} \mathrm{C}$. Rizzo and Muratore (2009) reported that unacceptable color change from green to yellow was more noticeable in controls, whereas MAs of celery leaves showed no signs of color change.

The postharvest storage retained high level of antioxidant under low temperature This findings concur with the study by Mudau et al. (2017), who reported that the antioxidant content were mostly retained at $4{ }^{\circ} \mathrm{C}$ when compared with 10 and $22{ }^{\circ} \mathrm{C}$. This could be attributed to metabolic reactions that are greatly reduced, although are not shut down completely. Pereira et al. (2014) experimented the effect of CA on the total antioxidant activity in the radicchio (Cichorium intybus $\mathrm{L}$.) when stored at $1{ }^{\circ} \mathrm{C}$ for $10 \mathrm{~d}$ and observed that there was a slight increase in the total antioxidant activity for first $3 \mathrm{~d}$ of storage, and thereafter declined drastically. Chu et al. (2002) stressed that there is no clear indication on the causes of antioxidant activity variation in the vegetables during storage. However, it is commonly understood that the antioxidant activity of vegetables totally depends on several compounds, such as flavonoids, phenolic acids, amino acids, and ascorbic acid.

Total flavonoids were well maintained at 4 and $10{ }^{\circ} \mathrm{C}$, whereas there was a drastic decline at $20^{\circ} \mathrm{C}$. Gil et al. (1999) reported an increase of total flavonoids in Swiss chard during storage at $6{ }^{\circ} \mathrm{C}$ under $\mathrm{CA}$, whereas this increase was not significant in the air-stored Swiss chard. The present study findings concurred with the study by Gil et al. (1999) in that there was no significant difference between the total flavonoids in plants stored in CA and those stored in normal air, except at high storage temperature. Elsewhere, Martínez-Sánchez et al. (2006) reported that the flavonoids content in the wild rocket leaves remained constant or even increased during storage when stored in CAs at temperature of 1.5 to $4{ }^{\circ} \mathrm{C}$ for $14 \mathrm{~d}$, whereas flavonoids in leaves stored under normal air kept on declining even when stored at low 
temperature. This could indicate that MAP can have pronounced effects of metabolism of phenolics depending on the variety or cultivar. Modified atmosphere packaging also plays a crucial role in reducing the oxygen level around the produce during storage, which inhibits the existence of aerobic microorganisms.

When considering all conditions under which this study was carried out, it has been found that baby spinach leaves stored under CA $\left(5 \% \mathrm{O}_{2} ; 15 \% \mathrm{CO}_{2}\right.$; balance $\left.\mathrm{N}_{2}\right)$ at $4{ }^{\circ} \mathrm{C}$ for $9 \mathrm{~d}$ maintained a high level of antioxidant activity and flavonoids. Common observation was that substantial losses of nutrients occurred at each storage temperature. Thus, it is ideal to apply a combination of control atmosphere and low temperature to promote longer shelf life without compromising the produce quality during storage.

\section{Literature Cited}

Antmann, G., G. Ares, P. Lema, and C. Lareo. 2008. Influence of modified atmosphere packaging on sensory quality of shiitake mushrooms. Postharvest Biol. Technol. 49:164-170.

Awika, J.M. and L.W. Rooney. 2004. Sorghum photochemical and their stability in sunflower oil and emulsion. Food Chem. 64:323-329.

Babic, I. and A.E. Watada. 1996. Microbial populations of fresh-cut spinach leaves affected by controlled atmospheres. Postharvest Biol. Technol. 9:187-193.

Chu, Y., J. Sun, X. Wu, and R.H. Liu. 2002. Antioxidant and antiproliferative activities of common vegetables. J. Agr. Food Chem. 50:6910-6916.

Church, I.J. and A.L. Parsons. 1995. Modified atmosphere packaging technology: A review. J. Sci. Food Agr. 67:143-152.

Conte, A., G. Conversa, C. Scrocco, I. Brescia, J. Laverse, A. Elia, and M.A. Del Nobile. 2008. Influence of growing periods on the quality of baby spinach leaves at harvest and during storage as minimally processed produce. Postharvest Biol. Technol. 50:190-196.

Gil, M.I., F. Ferreres, and F.A. Tomás-Barberan. 1999. Effect of postharvest storage and processing on the antioxidant constituents (flavonoids and vitamin $\mathrm{C}$ ) of fresh-cut spinach. J. Agr. Food Chem. 47:2213-2217.

Hanlon, E.A., J.G. Gonzalez, and J.M. Bartos. 1994. IFAS extension soil testing laboratory chemical procedure and training manual. Univ. Florida Coop. Ext. Serv., Circ. 812.

Izumi, H., T. Nonaka, and T. Muraoka. 1997. Physiology and quality of fresh-cut spinach stored in low $\mathrm{O}_{2}$ controlled atmospheres at various temperatures, p. 130-133. In: J.R.
Gorny (ed.). Fresh-Cut Fruits and Vegetables and MAP, CA'97 Proceedings, Vol. 5. University of California, Davis, CA.

Kaur, P., D.R. Rai, and S. Paul. 2011. Quality changes in fresh-cut spinach (Spinacia oleracea) under modified atmospheres with perforations. J. Food Qual. 34:10-18.

Ko, N.P., A.E. Watada, D.V. Schlimme, and J.C. Bouwkamp. 1996. Storage of spinach under low oxygen atmosphere above the extinction point. J. Food Sci. 61:398-401.

Kou, L., Y. Luo, E. Park, E.R. Turner, A. Barczak, and W.M. Jurick. 2014. Temperature abuse timing affects the rate of quality deterioration of commercially packaged ready-to-eat baby spinach. Part I: Sensory analysis and selected quality attributes. Postharvest Biol. Technol. 91:96-103.

Leceta, I., S. Molinaro, P. Guerrero, J.P. Kerry, and K. de la Caba. 2015. Quality attributes of map packaged ready-to-eat baby carrots by using chitosan-based coatings. Postharvest Biol. Technol. 100:142-150.

Mampholo, B.M., D. Sivakumar, M. Beukes, and W.J. Rensburg. 2013. Effect of modified atmosphere packaging on the quality and bioactive compounds of Chinese cabbage (Brasicca rapa L. ssp. chinensis). J. Sci. Food Agr. 93:20082015.

Martínez-Sánchez, A., A. Allende, R.N. Bennett, F. Ferreres, and M.I. Gil. 2006. Microbial, nutritional and sensory quality of rocket leaves as affected by different sanitizers. Postharvest Biol. Technol. 42:86-97.

Mastromatteo, M., A. Conte, and M.A. Del Nobile. 2012. Packaging strategies to prolong the shelf life of fresh carrots (Daucus carota L.). Innov. Food Sci. Emerg. Technol. 13:215-220.

Medina, M.S., J.A. Tudela, A. Marín, A. Allende, and M.I. Gil. 2012. Short postharvest storage under low relative humidity improves quality and shelf life of minimally processed baby spinach (Spinacia oleracea L.). Postharvest Biol. Technol. 67:1-9.

Mir, N. and R.M. Beaudry. 2004. Modified atmosphere packaging. 15 Nov. 2017. <http://www. ba.ars.usda.gov/hb66/015map.pdf>.

Mudau, A.R., M. Nkomo, P. Soundy, H.T. Araya, W. Ngezimana, and F.N. Mudau. 2015. Influence of Post-harvest storage temperature and duration on quality of baby spinach. HortTechnology 25:665-670.

Mudau, A.R., P. Soundy, and F.N. Mudau. 2017. Response of baby spinach (Spinacia oleracea L.) to photo-selective nettings on growth and postharvest quality. HortScience 52:719-724.

Munhuweyi, K., U.L. Opara, and G. Sigge. 2016. Postharvest losses of cabbages from retail to consumer and the socio-economic and environmental impacts. Brit. Food J. 118:286-300.

Nemadodzi, L., H.T. Araya, M. Nkomo, W. Ngezimana, and F.N. Mudau. 2017. Response of physiological and biomass production of baby spinach (Spinacia oleracea L.) leafy vegetable to nitrogen, phosphorus and potassium nutrition. J. Plant Nutr. 40:2033-2044.

Ninfali, P. and M. Bacchiocca. 2004. Parameters for the detection of post-harvest quality in fresh or transformed horticultural crops. J. Food Agr. Environ. 2:122-127.

Pandrangi, S. and L.F. LaBorde. 2004. Retention of folate, carotenoids, and other quality characteristics in commercially packaged fresh spinach. J. Food Sci. 69:702-707.

Pereira, G.D.M., C.I. Kothe, C.C. Machado, S.M. Lopes, S.H. Flôres, and A.D.O. Rios. 2014. Effect of modified atmosphere applied to minimally processed radicchio (Cichorium intybus L.) submitted to different sanitizing treatments. Food Sci. Technol. 34:513521.

Rizzo, V. and G. Muratore. 2009. Effects of packaging on shelf life of fresh celery. J. Food Eng. 90:124-128.

Sandhya.. 2010. Modified atmosphere packaging of fresh produce: Current status and future needs. Food Sci. Technol. 43:381-392.

Tudela, J.A., A. Marín, A. Martínez-Sánchez, M.C. Luna, and M.I. Gil. 2013. Preharvest and postharvest factors related to off-odors of fresh-cut iceberg lettuce. Postharvest Biol. Technol. 86:463-471.

van der Walt, A.M., D.T. Loots, M.I.M. Ibrahim, and C.C. Bezuidenhout. 2009. Minerals, trace elements and antioxidant phytochemicals in wild African dark-green leafy vegetables (morogo). S. Afr. J. Sci. 105:11-12.

Velickova, E., E. Winkelhausen, S. Kuzmanova, V.D. Alves, and M. Moldão-Martins. 2013. Impact of chitosan-beeswax edible coatings on the quality of fresh strawberries (Fragaria ananassa cv Camarosa) under commercial storage conditions. Food Sci. Technol. 52:80 92.

Watada, A.E., S.D. Kim, K.S. Kim, and T.C. Harris. 1987. Quality of green beans, bell peppers and spinach stored in polyethylene bags. J. Food Sci. 52:1637-1641.

Yoo, K.M., C.H. Lee, H. Lee, B. Moon, and C.Y. Lee. 2008. Relative antioxidant and cytoprotective activities of common herbs. Food Chem. 106:92-96.

Zagory, D. and A.A. Kader. 1988. Modified atmosphere packaging of fresh produce. Food Technol. 42:70-77.

Zenoozian, M.S. 2011. Combined effect of packaging method and temperature on the leafy vegetables properties. Intl. J. Environ. Sci. Dev. 2:124-127.

Zikalala, B.O., M. Nkomo, H.T. Araya, W. Ngezimana, and F.N. Mudau. 2016. Nutritional quality of baby spinach (Spinacia oleracea L.) as affected by nitrogen, phosphorus and potassium fertilization. S. Afr. J. Plant Soil 4:1-8. 